Vol. 5 (1996): 387-397.

\title{
Detection of bias in animal model pedigree indices of heifers
}

\author{
Martin Lidauer and Esa Mäntysaari \\ Agricultural Research Centre of Finland, Institute of Animal Production, FIN-31600 Jokioinen, Finland
}

\begin{abstract}
The objective of the study was to test whether the pedigree indices (PI) of heifers are biased, and if so, whether the magnitude of the bias varies in different groups of heifers. Therefore, two animal model evaluations with two different data sets were computed. Data with all the records from the national evaluation in December 1994 was used to obtain estimated breeding values (EBV) for 305days' milk yield and protein yield. In the second evaluation, the PIs were estimated for cows calving the first time in 1993 by excluding all their production records from the data. Three different statistics, a simple t-test, the linear regression of EBV on PI, and the polynomial regression of the difference in the predictions (EBV-PI) on PI, were computed for three groups of first parity Ayrshire cows: daughters of proven sires, daughters of young sires, and daughters of bull dam candidates.

A practically relevant bias was found only in the PIs for the daughters of young sires. On average their PIs were biased upwards by 0.20 standard deviations $(78.8 \mathrm{~kg}$ ) for the milk yield and by 0.21 standard deviations $(2.2 \mathrm{~kg})$ for the protein yield. The polynomial regression analysis showed that the magnitude of the bias in the PIs changed somewhat with the size of the PIs.
\end{abstract}

Key words: Ayrshire, breeding value estimation, milk yield, protein yield, polynomial regression

\section{Introduction}

New breeding policies give more emphasis on the selection of the best bull dams for breeding as young as possible. In Finland, about five percent of the selected bull dams are heifers (Auli Himanen, personal communication). The selection of those heifers is based on the pedigree index (PI), the average of the parents' estimated breeding values, as they do not have their own test records. An optimal utilization of such breed- ing policies requires accurate and unbiased breeding value estimates for bulls and cows. A considerable increase in the accuracy of the cows' estimated breeding values (EBV) can be achieved if the evaluation is based on an animal model-BLUP (best linear unbiased prediction) methodology. Though the BLUP-estimates are characteristically unbiased, and an animal model utilizes all available data from the relatives, the EBVs can be substantially biased if the model is not correctly specified (e.g., Mäntysaari and Sillanpää 1993, Harbers et al. 1994). Particular-

(C) Agricultural and Food Science in Finland

Manuscript received May 1996 


\section{AGRICULTURAL AND FOOD SCIENCE IN FINLAND}

\section{Lidauer, M. \& Mäntysaari, E. Detection of bias in animal model pedigree indices of heifers}

ly the pedigree indices (PI) of young sires are often considerably higher than their future EBVs based on progeny testing (Ferris and Wiggans 1991, Mao et al. 1991, van der Werf et al. 1994, Zhang et al. 1994). One source of the bias can be a heterogeneous intraherd variance, which can be caused by reasons like small herd sizes (Uimari and Mäntysaari 1995), or upgrading of the breed, but also if animals of the same herd do not have the same environment; e.g., the superior cows could receive more attention from the farmer than their herd mates. A bias in the EBVs can also be caused by the use of inappropriate variance components as discussed by Reverter et al. (1994).

In Finland a single trait animal model has been used since 1990 for the estimation of breeding values for dairy cattle (Mäntysaari and Strandén 1991, Strandén and Mäntysaari 1992). Uimari and Mäntysaari (1993) studied the reliability of the estimation, and found that the PIs of young sires for 305-days' protein yield were on average 0.48 standard deviations $(5.2 \mathrm{~kg})$ higher than their later EBVs; a bias, which might have been due to a preferred herd environment for bull dams. A bias which arises from the problem of small herd sizes was addressed by Mäntysaari and Sillanpää (1993). With a redefinition of the herd effect they could reduce the bias in the PIs of young sires by $57 \%$. In a following study to the work of Uimari and Mäntysaari (1993), the same authors (1995) found an upward bias in the PIs of young sires of 1.25 standard deviations $(13.6 \mathrm{~kg})$ in protein. They explained this considerably larger bias by the different set of bulls considered, and the higher heritability $(0.30$ versus 0.25$)$ used in this study. Similarly to Wilhelm and Mao (1989), they found that the bulls coming from small herds tend to have more upward biased PIs than the bulls coming from larger herds. In those earlier works authors argued that the model still ranked average merit cows accurately, although it had problems with the ranking of bull dams. Based on the results of those studies, important adjustments in the herd effect definition of the animal model were introduced to reduce the bias.
The objective of our study was to investigate the magnitude of a possible remaining bias, and whether the bias is larger in the PIs of animals at the extremes. All the earlier Finnish studies have centred on young sire PIs and corresponding EBVs. This, because sires' EBVs based on more than 100 daughters can be considered as a reliable control. In contrast to those works, our study emphasises the bias in the PIs of three different types of heifers: (1) daughters of proven sires; (2) daughters of young sires; (3) daughters of bull dam candidates. Biased PIs of daughters of proven sires would indicate that the bias originated from their dams, since the EBVs of the proven sires can be considered as reliable. Given from earlier studies that the PIs of young sires are biased, we can expect that the PIs of daughters of young sires will have $50 \%$ of that bias before they make a record. The third type of heifers was investigated because it is likely that superior cows are treated preferentially, which might cause biased PIs. Three different statistics were applied to test the deviations between the two consecutive evaluations against their expectations.

\section{Material and methods}

To obtain two breeding values for each cow, a PI and an EBV, two different data sets were formed. The data for estimating the more accurate breeding values was the same as used in the national evaluation in December 1994. The data contained all available first, second and third lactation records of cows calved between 1978 and 1994 of the three national dairy breeds Ayrshire, Finnish Friesian and Finncattle. It included the records of 1189692 cows, and through pedigree structures, altogether 1448967 cows and 8844 bulls. A second, reduced data set was constructed from the first data by excluding all records of cows that had calved for the first time after March 1993. A cow with excluded records, whose breeding value was estimated with this 
Vol. 5 (1996): 387-397.

data set, was treated as if it would be a heifer and hence, its breeding value becomes estimated as the average of its parents' EBVs, i.e. PI.

The PIs and the EBVs for 305-days' milk yield and protein yield were calculated with a single trait animal model using the same statistical model as is currently used in the national evaluation.

$\mathrm{Y}_{i j k l m n}=\mathrm{f}_{i}+\mathrm{m}_{j}+\mathrm{c}_{k}+\mathrm{h}_{l}+\mathrm{a}_{m}+\mathrm{p}_{n}+\mathrm{e}_{i j k l m n}$

where $\mathrm{Y}_{i j k l m n}$ is the observation $n$ for cow $m$, fixed effects are herd $\times$ period of five years $\times$ parity group $\left(\mathrm{f}_{i}\right)$, year $\times$ calving season $\left(\mathrm{m}_{j}\right)$, and parity $\times$ calving age $\times$ days open group $\left(c_{k}\right)$, and random effects are herd $\times$ year $\times$ parity group $\left(h_{l}\right)$, animal $\left(\mathrm{a}_{m}\right)$, permanent environment $\left(\mathrm{p}_{m}\right)$, and residual $\left(\mathrm{e}_{i j k l m n}\right)$. There are 6 calving season classes per year (February-March, April-May, ...), 18 calving age classes ( 6 per parity) and 6 days open classes. There are two parity groups; one for the first parity and another for the second and third parity. The way the herd effect is modelled has been found to be effective in reducing the prediction bias in the bull dam EBVs in Finnish circumstances (Mäntysaari and Sillanpää 1993, Uimari and Mäntysaari 1995). After the seventh round of iteration, the records are multiplicatively precorrected for the effects of calving season and parity $\times$ calving age. This is done to standardize the variance of records partially in different calving seasons and parities. The model does not account for non-additive genetic effects between breeds. All breeds are evaluated simultaneously, and the breed differences are modelled through parental groups. These are defined according to the breed and the year of birth of the base population animals. For both traits the used variance ratios were the same. The heritability was 0.3 , the repeatability was 0.5 , and the variance ratio residual / herd-year was 1.82 .

In the reduced data, 97247 first parity cows fulfilled the editing rule and their records were excluded. From those, 51744 Ayrshire cows were used to form three different groups: 1) Cows, which were second crop daughters of proven sires. 2) Cows, which were daughters of young sires. The sires were born after 1988 and had not more than five progeny with records in the reduced data set, but received their first evaluations with the full data. 3) Cows, which were daughters of bull dam candidates; defined by having their dams' indices for protein yield more than two standard deviations above the population mean.

The observed bias was estimated as an average difference between the EBV and the PI. Three different procedures were applied to judge the significance of the bias:

1. A simple t-test for testing a deviation of the empirical bias from zero.

$$
t=\frac{\overline{E B V-P I}}{\sqrt{\frac{1}{n} \operatorname{Var}((E B V-P I))}}
$$

It was assumed that the differences (EBVPI) are independently and identically distributed (iid).

2. The linear regression of EBV on PI, as proposed by Reverter et al. (1994), which has an expectation of the value 1 .

$\mathrm{b}_{E B V, P I}=\frac{\operatorname{Cov}(\mathrm{EBV}, \mathrm{PI})}{\operatorname{Var}(\mathrm{PI})}$

For statistical testing it was assumed that conditionally on PI the EBVs are iid.

3. A polynomial regression analysis was used to test if there is a relationship between the bias and the magnitude of the PI; i.e., are the PIs of superior animals more biased than the PIs of average or below average animals? Therefore three different models were applied:

$(\mathrm{EBV}-\mathrm{PI})_{i}=\mathrm{b}_{0}+\mathrm{b}_{1} \mathrm{PI}_{i}+\mathrm{e}_{i}$

$(\mathrm{EBV}-\mathrm{PI})_{i}=\mathrm{b}_{0}+\mathrm{b}_{1} \mathrm{PI}_{i}+\mathrm{b}_{2} \mathrm{PI}_{i}^{2}+\mathrm{e}_{i}$

$(\mathrm{EBV}-\mathrm{PI})_{i}=\mathrm{b}_{0}+\mathrm{b}_{1} \mathrm{PI}_{i}+\mathrm{b}_{2} \mathrm{PI}_{i}^{2}+\mathrm{b}_{3} \mathrm{PP}_{i}^{3}+\mathrm{e}_{i}$

were $\mathrm{b}_{0}$ is an intercept, $\mathrm{b}_{1}, \mathrm{~b}_{2}$ and $\mathrm{b}_{3}$ are partial regression coefficients and $\mathrm{e}_{i}$ is the residual. Again, it was assumed that the residual is iid. If a difference between EBV and PI would only be caused by Mendelian sampling, one would ex- 
Lidauer, M. \& Mäntysaari, E. Detection of bias in animal model pedigree indices of heifers

Table 1. Means and standard deviations (SD) of pedigree indices (PI) and estimated breeding values (EBV) for milk yield and protein yield for three groups of first parity Ayrshire cows.

\begin{tabular}{|c|c|c|c|c|}
\hline & & $\begin{array}{l}\text { Daughters of } \\
\text { proven sires }\end{array}$ & $\begin{array}{l}\text { Daughters of } \\
\text { young sires }\end{array}$ & $\begin{array}{c}\text { Daughters of bull } \\
\text { dam candidates }\end{array}$ \\
\hline Number of cow & & 34444 & 17128 & 1010 \\
\hline Number of sire: & & 319 & 131 & 263 \\
\hline \multicolumn{5}{|l|}{ Milk yield (kg) } \\
\hline \multirow[t]{2}{*}{ PI } & Mean & 413.79 & 428.47 & 766.91 \\
\hline & SD & 242.00 & 181.40 & 194.44 \\
\hline \multirow[t]{2}{*}{ EBV } & Mean & 418.17 & 349.66 & 760.58 \\
\hline & SD & 277.94 & 257.52 & 255.08 \\
\hline \multicolumn{5}{|c|}{ Protein yield $(\mathrm{kg})$} \\
\hline \multirow[t]{2}{*}{ PI } & Mean & 13.38 & 14.03 & 25.32 \\
\hline & SD & 6.23 & 5.09 & 4.66 \\
\hline \multirow[t]{2}{*}{ EBV } & Mean & 13.57 & 11.86 & 25.48 \\
\hline & SD & 7.60 & 7.35 & 6.88 \\
\hline
\end{tabular}

pect that the intercept and the partial regression coefficients are zero.

The reliability of the proven sires' EBVs (on average $r^{2}=0.96$ ) was high enough to assume that the changes in their EBVs had no significant influence on the polynomial regression analysis for the daughters of proven sires. This did not hold for the daughters of young sires. Therefore, in an additional approach the sire of the daughter ( sire $_{i}$ ) was included as a fixed effect into the models.

$$
\begin{aligned}
(\mathrm{EBV}-\mathrm{PI})_{i}= & \operatorname{sire}_{i}+\mathrm{b}_{0}+\mathrm{b}_{1} \mathrm{PI}_{i}+\mathrm{e}_{i} \\
(\mathrm{EBV}-\mathrm{PI})_{i}= & \operatorname{sire}_{i}+\mathrm{b}_{0}+\mathrm{b}_{1} \mathrm{PI}_{i}+\mathrm{b}_{2} \mathrm{PI}_{i}^{2}+\mathrm{e}_{i} \\
(\mathrm{EBV}-\mathrm{PI})_{i}= & \operatorname{sire}_{i}+\mathrm{b}_{0}+\mathrm{b}_{1} \mathrm{PI}_{i}+\mathrm{b}_{2} \mathrm{PI}_{i}^{2}+\mathrm{b}_{3} \\
& \mathrm{PI}_{i}^{\mathrm{B}}+\mathrm{e}_{i}
\end{aligned}
$$

\section{Results}

From the first parity Ayrshire cows, the daughters of proven sires formed the biggest group with a total number of 34444 cows with 319 different sires (Table 1). A share of 17128 cows were daughters of 131 different young sires, and 1010 cows with 263 different sires met the cri- terion being daughters of bull dam candidates. A group of 627 daughters of proven sires and 211 daughters of young sires also belonged to the daughters of bull dam candidates.

In the group of daughters of proven sires the average differences EBV-PI, i.e. the bias in the PIs, of $4.38 \mathrm{~kg}$ in milk and $0.23 \mathrm{~kg}$ in protein were statistically significant but very small; 0.01 and 0.02 standard deviations, respectively (Table 2). On the contrary, for the daughters of young sires a clear upward bias in their PIs, of $78.81 \mathrm{~kg}$ in milk and $2.17 \mathrm{~kg}$ in protein, was found. The average differences EBV-PI of -6.33 $\mathrm{kg}$ in milk and $0.16 \mathrm{~kg}$ in protein for the daughters of bull dam candidates were not significant. The regression coefficients differed significantly from the expected values in all but one case (Table 2). Only the estimate of protein yield $\left(b_{(E B V, P I)}=0.993\right)$ for the daughters of proven sires was not significantly different from one. With a polynomial regression analysis, dependencies between the size of the bias in the PIs and the magnitude of the PIs were found for both traits in each group. Intercepts and partial regression coefficients of the model with the highest, still significant order are listed in Table 3.

The linear regression model (1) was sufficient for both the traits in the daughters of bull dam 
Vol. 5 (1996): 387-397.

Table 2. Mean differences between estimated breeding values (EBV) and pedigree indices (PI), and regression coefficient $b_{(E B V, P I)}$ for the two traits, milk yield and protein yield, for three groups of first parity Ayrshire cows.

\begin{tabular}{|c|c|c|c|c|}
\hline & & $\begin{array}{l}\text { Daughters of } \\
\text { proven sires }\end{array}$ & $\begin{array}{l}\text { Daughters of } \\
\text { young sires }\end{array}$ & $\begin{array}{c}\text { Daughters of bull } \\
\text { dam candidates }\end{array}$ \\
\hline \multicolumn{5}{|c|}{ Milk yield (kg) } \\
\hline \multirow[t]{2}{*}{ EBV-PI } & Mean & $4.38 * * *$ & $-78.81 * * *$ & $-6.33^{\mathrm{ns}}$ \\
\hline & $\mathrm{SD}^{a}$ & 143.79 & 188.51 & 184.76 \\
\hline \multicolumn{2}{|l|}{$\mathbf{b}_{(E B V, P I)}$} & $0.983^{* * *}$ & $0.968 * * *$ & $0.909 * *$ \\
\hline \multicolumn{5}{|c|}{ Protein yield $(\mathbf{k g})$} \\
\hline \multirow[t]{2}{*}{ EBV-PI } & Mean & $0.23 * * *$ & $-2.17^{* * *}$ & $0.16^{\mathrm{ns}}$ \\
\hline & SD & 4.40 & 5.68 & 5.49 \\
\hline $\mathbf{b}_{(E B V P I)}$ & & 0.993 ns & $0.920 * * *$ & $0.895 * *$ \\
\hline
\end{tabular}

Significance levels: ${ }^{* * *} \mathrm{P} \leq 0.001,{ }^{* *} \mathrm{P} \leq 0.01,{ }^{\mathrm{ns}}$ not significant.

aD: Standard deviation.

Table 3. Coefficient of determination $\left(\mathrm{R}^{2}\right)$, intercepts $\left(\mathrm{b}_{0}\right)$ and partial regression coefficients $\left(\mathrm{b}_{1}, \mathrm{~b}_{2}\right)$ for polynomial regressions of the difference in the predictions (EBV-PI) on PI for the two traits, milk yield and protein yield, for three groups of first parity Ayrshire cows.

\begin{tabular}{cccc}
\hline & $\begin{array}{c}\text { Daughters of } \\
\text { proven sires }\end{array}$ & $\begin{array}{c}\text { Daughters of } \\
\text { young sires }\end{array}$ & $\begin{array}{c}\text { Daughters of bull } \\
\text { dam candidates }\end{array}$ \\
\hline $\begin{array}{l}\text { Milk yield }(\mathbf{k g}) \\
\mathrm{R}^{2}\end{array}$ & 0.0008 & & \\
$\mathrm{~b}_{0}$ & $11.4094^{* * *}$ & $-53.4989 * * *$ & 0.0092 \\
$\mathrm{~b}_{\text {l }}$ & $-0.0170 * * *$ & $-0.0967 * * *$ & $63.4398^{* *}$ \\
$\mathrm{~b}_{2}$ & $\mathrm{~ns}$ & $0.0000744^{*}$ & $-0.0910^{* *}$ \\
Protein yield $(\mathbf{k g})$ & & & $\mathrm{ns}$ \\
$\mathrm{R}^{2}$ & 0.0005 & 0.0053 & 0.0079 \\
$\mathrm{~b}_{0}$ & $0.5442^{* * *}$ & $-0.6176^{*}$ & $2.8159 * *$ \\
$\mathrm{~b}_{1}$ & $-0.0485 * * *$ & $-0.1497 * *$ & $-0.1050 * *$ \\
$\mathrm{~b}_{2}$ & $0.00155 * * *$ & $0.00246 *$ & $\mathrm{~ns}$ \\
\hline
\end{tabular}

Significance levels: ${ }^{* * *} \mathrm{P} \leq 0.001,{ }^{* *} \mathrm{P} \leq 0.01,{ }^{*} \mathrm{P} \leq 0.05$, ns not significant.

candidates, and for the milk yield in the daughters of proven sires. Based on the regression, the bias in the PIs for the milk yield for the daughters of bull dam candidates becomes zero when the PIs are 0.4 standard deviations below the mean of the PIs (697 kg), and from there it increases $0.091 \mathrm{~kg}$ per each unit increase in the PI. In the daughters of proven sires, the bias in the PIs for milk is zero when the PIs are 1.1 standard deviations above the mean of the PIs $(671 \mathrm{~kg})$, and from there it increases $0.017 \mathrm{~kg}$ per each unit increase in the PI (Figure 1).
The quadratic polynomial regression effect in model (2) was significant for the protein yield for the daughters of proven sires, meaning that the bias in the PIs of heifers increased quadratically the further away the PIs were from the mean. As an example of PIs being 2 standard deviations above the mean, the mathematical equation predicts that the future EBVs will be $0.33 \mathrm{~kg}$ higher than expected (Table 4$)$. The regression model (2) was also significant for both traits in the daughters of young sires (Table 3). For the milk yield, the quadratic polynomial re- 


\section{AGRICULTURAL AND FOOD SCIENCE IN FINLAND}

Lidauer, M. \& Mäntysaari, E. Detection of bias in animal model pedigree indices of heifers

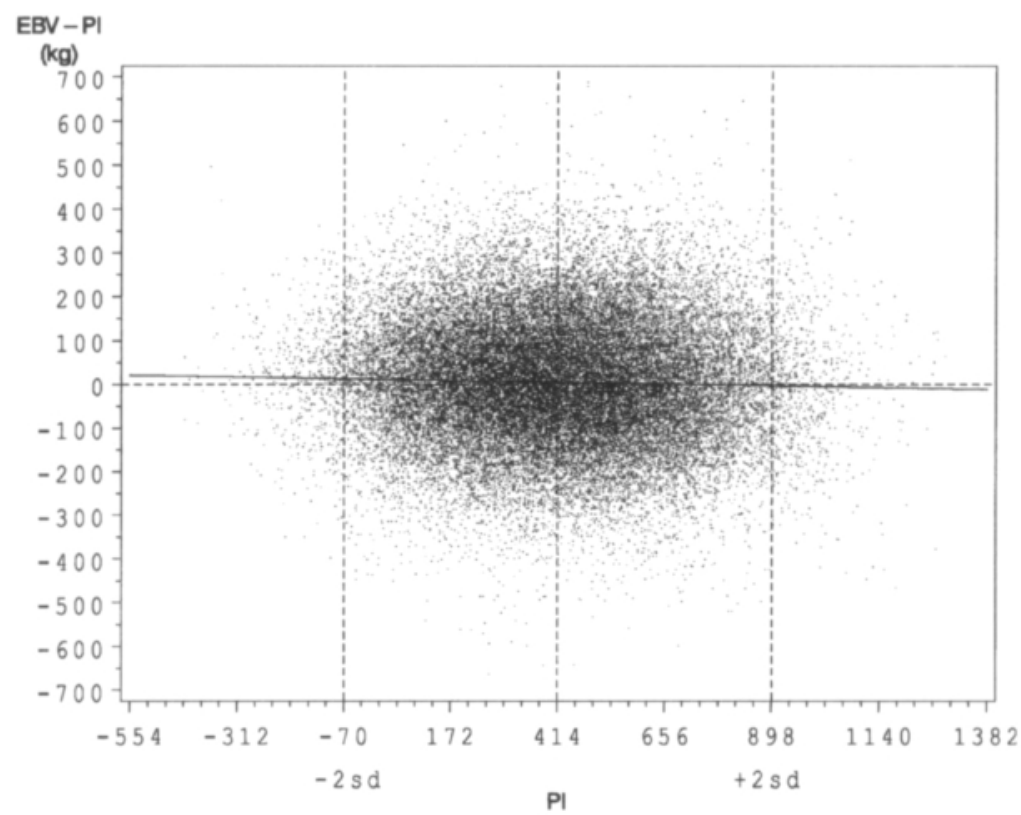

Fig. 1. Scatterplot of the difference EBV-PI against the values of the PIs for the milk yield $(\mathrm{kg})$ in the daughters of proven sires. The line represents the linear regression of the bias (EBV-PI) on the PI.

gression (Figure 2) indicates that the PIs 2 standard deviations below the mean were biased by $-60 \mathrm{~kg}$, the average PIs were biased by $-81 \mathrm{~kg}$ and the PIs 2 standard deviations above the mean were biased by $-83 \mathrm{~kg}$ (Table 4 ). After the inclusion of the sire into the model, the quadratic polynomial regression (5) remained significant only for the milk yield $\left(\mathrm{b}_{1}=-0.0407, \mathrm{P}=0.033\right.$; $\left.\mathrm{b}_{2}=0.0000557, \mathrm{P}=0.008\right)$. This polynomial suggests that the bias in the PIs was not only caused by the sire (Figure 3 ). The cubic polynomial regression model (3) was not significant in any group.

Table 4. Difference between estimated breeding value (EBV) and pedigree index (PI) according to the results of the polynomial regression analysis tabulated for different values of PI and different categories of heifers.

\begin{tabular}{lccccr}
\hline & & & \multicolumn{2}{c}{ EBV-PI for 3 different PI-values (kg) } \\
\cline { 5 - 6 } Category of heifers & Trait & Model $^{\mathrm{a}}$ & $-2 \mathrm{SD}^{\mathrm{b}}$ & Mean & +2 SD $^{\mathrm{b}}$ \\
\hline \multirow{2}{*}{ daughters of proven sires } & milk & 1 & 12.61 & 4.38 & -3.85 \\
& protein & 2 & 0.50 & 0.17 & 0.33 \\
daughters of young sires & milk & 2 & -59.53 & -81.27 & -83.43 \\
& protein & 2 & -1.16 & -2.23 & -2.80 \\
daughters of bull dam & milk & 1 & 29.08 & -6.33 & -41.74 \\
candidates & protein & 1 & 1.14 & 0.16 & -0.81 \\
\hline
\end{tabular}

"Model 1: linear regression model, model 2: quadratic regression model.

${ }^{\mathrm{b}} \mathrm{SD}$ : standard deviation. 
Vol. 5 (1996): 387-397.

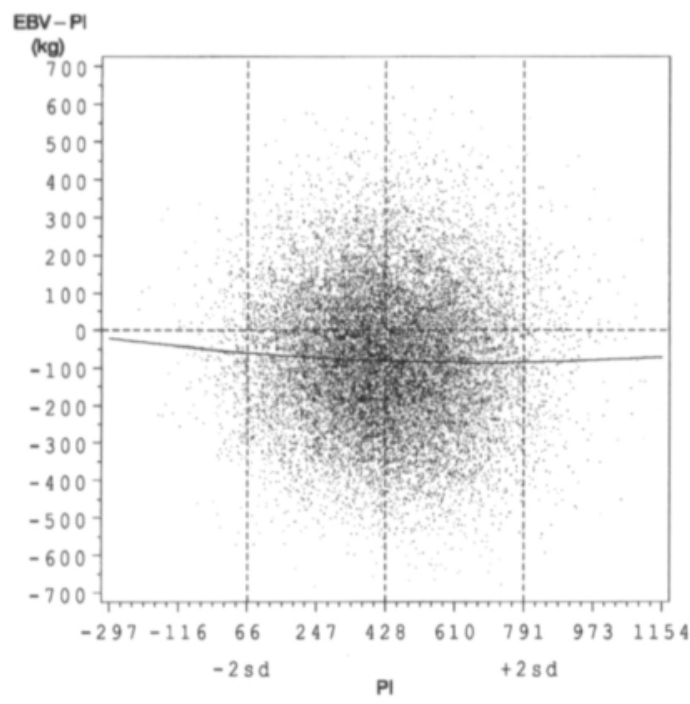

Fig. 2. Scatterplot of the difference EBV-PI against the values of the PIs for the milk yield $(\mathrm{kg})$ in the daughters of young sires. The curve represents the polynomial regression of the bias (EBV-PI) on the PI.

\section{Discussion}

In the study, a clear bias was detected only in the PIs for the daughters of young sires. The PIs overpredicted the EBVs on average by $78.8 \mathrm{~kg}$ for the milk yield and by $2.2 \mathrm{~kg}$ for the protein yield. This bias is mainly a result of overpredicted PIs for young sires, as the PIs of the daughters of proven sires were not considerably biased. Thus, the overprediction in the PIs for young sires is about twice as big as in the PIs for their daughters. The bias in our study was considerably smaller than the one found by Uimari and Mäntysaari (1993 and 1995). This might be partially due to a redefinition of the herd effect as described by Mäntysaari and Sillanpää (1993). They found that a fixed herd $x$ year $\times$ parity group effect would be most effective to reduce the bias, but because the herds are very small it would lead to a situation in which about $20 \%$ of the first lactating cows would have no contemporaries in their groups. As a better alternative, periods of five years instead of one

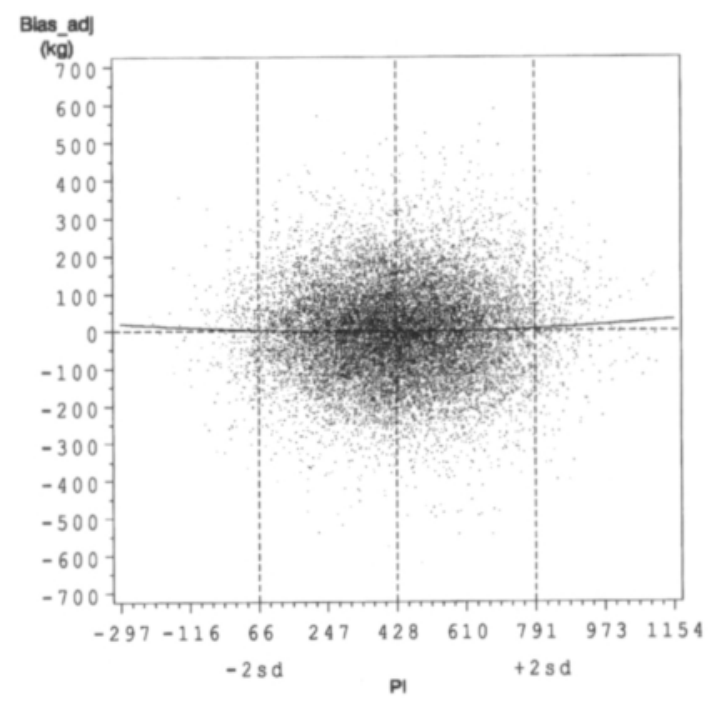

Fig. 3. Scatterplot of the adjusted empirical bias (Bias ${ }_{\text {add }}$ ) against the values of the PIs for the milk yield $(\mathrm{kg})$ in the daughters of young sires. The difference EBV-PI was adjusted by the sire effect; Bias ${ }_{a d j}=(\text { EBV-PI })_{i}-$ sire $_{i}$. The curve represents the polynomial regression of $\mathrm{Bias}_{\text {adj }}$ on the PI based on the following model: Bias $_{a d j}=\mathrm{b}_{0}+\mathrm{b}_{I} \mathrm{PI}_{i}+\mathrm{b}_{2} \mathrm{PI}^{2}{ }_{i}$ $+\mathrm{e}_{i}$.

year, and a random herd $\times$ year $\times$ parity group effect were implemented into the model.

The EBVs of cows with proven sires differed on average only little from their PIs (Table 2). Due to the higher number of observations, the differences were significant but practically negligible. Hence, when a heifer has a progeny tested sire, her PI can be considered as a reliable predictor of her future EBV.

On average, the EBVs of the daughters of bull dam candidates did not significantly differ from their PIs. This was somehow unexpected, since it has been observed in several studies that EBVs of bull dams are biased upwards (e.g. Kuhn et al. 1994, Zhang et al. 1994). The obtained results may reflect the circumstance that the heifers of bull dam candidates were in the same herds as their dams and therefore received the same attention as their dams, since they are expected to become bull dams of the next generation. A similar result has been found by Powell and 


\section{AGRICULTURAL AND FOOD SCIENCE IN FINLAND}

\section{Lidauer, M. \& Mäntysaari, E. Detection of bias in animal model pedigree indices of heifers}

Norman (1988). According to their study the daughters of superior dams performed even better than predicted.

The regression coefficients $b_{(E B V, P I)}$ were much closer to the expectation compared with the corresponding value of 0.65 found by Uimari and Mäntysaari (1995). In the daughters of proven sires, i.e., the group where the PIs were hardly biased at all, the regression coefficient for protein was not significantly different from the expected value, and for milk (0.983) still very close to the expectation. Reverter et al. (1994) claimed that such a condition as the use of inappropriate variance components can cause this regression to deviate from its expectation. Uimari and Mäntysaari (1995) found an over two times larger bias than the one they found in their previous study (Uimari and Mäntysaari 1993) and suggested this to be because of a different heritability $(0.30$ versus 0.25$)$ used in the evaluation and a different set of bulls considered. They were, however, using the model for the national evalutations computed prior 1993 where a common herd-year effect was applied on all the lactations. This ignored the herd $\times$ parity interaction that was found to be a major reason for the bias in young sires' PIs (Mäntysaari and Sillanpää 1993). Therefore, the regression coefficients found in our study suggest that the heritability of 0.30 is appropriate for the current model.

The polynomial regression analysis was used to clarify if the obtained results hold for the PIs of animals at the extremes. Though statistically significant regression coefficients were found for both traits in all the three groups, the coefficients of determination were very small $\left(R^{2} \leq 0.0092\right)$. This means that the magnitude of the bias depends somewhat on the size of the PI, but overall it is of little practical relevance. The fact that significant regressions coefficient were found indicates that the assumptions for the t-test may have been violated, since the differences (EBVPI) depended on the size of the PIs.

The linear regression model (1) was sufficient for both traits in the daughters of bull dam candidates, and for the milk yield in the daughters of proven sires. This suggests that the PIs of animals at the upper extremes of these groups tended to be biased upwards. To some extent, this might be due to a preferential treatment of the heifers' dams. Accordingly, for animals at the lower extremes, the PIs tended to underpredict the first EBVs. A similar result was found by Powell and Norman (1988). They explained it by the unfortunate environmental conditions of their dams not considered in the estimation (i.e., injuries and diseases). As a consequence, the dams' EBVs and their daughters' PIs become underestimated. Note that the regression coefficients (b,'s) of model (1) are consistent with the $\mathrm{b}_{(E B V, P I)}$ 's, since $\mathrm{b}_{l}=\mathrm{b}_{(E B V, P I)}-\operatorname{cov}(\mathrm{PI}, \mathrm{PI}) / \mathrm{var}(\mathrm{PI})$ $=\mathrm{b}_{(E B V, P I)}-1$.

The coefficients of the quadratic model (2) were significant for the protein yield in the daughters of proven sires, and for both traits in the daughters of young sires. However, the form of the quadratic equation was different. For the daughters of proven sires the upward concavity suggests that the PIs at the extremes underpredicted the first EBVs more than the PIs closer to the mean. But again, this bias is practically negligible (Table 4). For the daughters of young sires the bias in milk (Figure 2) was largest for the PIs with a value between the mean $(428 \mathrm{~kg})$ and 2 standard deviations above the mean $(791 \mathrm{~kg})$. For the milk, the regression coefficients remained significant even when the sire was included (model 5). Then the regression coefficients were clearly smaller and described an upward concavity with its minimum 0.35 standard deviations below the mean (Figure 3). This curve represents the empirical bias adjusted for the sire effect, i.e. adjusted for the amount of bias which can be found in each daughter of the same sire. The concavity gives evidence that to a small extent, the bias in the PIs is due to a bias in dams' EBVs. At the lower extreme, the curve is in agreement with the findings of Powell and Norman (1988) as cited above. At the upper extreme the curve suggests that on average superior heifers have performed better than predicted by their dams.

The reason why the PIs of the superior heifers of proven sires were biased upwards (Figure 


\section{AGRICULTURAL AND FOOD SCIENCE IN FINLAND}

Vol. 5 (1996): 387-397.

1) and the PIs of superior heifers of young sires were biased downwards when the bias was adjusted for the sire effect (model (5), Figure 3) remains unclear. According to the Finnish practice, the daughters of proven sires descend from better dams, which might partially have received special attention. Hence, the dams' EBVs and consequently the PIs of their daughters would be biased upwards. For such heifers it is hard to perform according to their expectations or better, even if they receive preferential treatment as well. In contrast, the heifers of young sires are mainly the first offspring of their dams. For those dams preferential treatment is rather unlikely, since they represent a random sample of the population. By the time when such a heifer starts her first lactation, her dam will be in the third lactation. If the dam has performed excellently, naturally, her progeny will receive additional care from the farmer, which enables the daughter to perform better than predicted.

In the group of daughters of young sires, none of the coefficients in the models (4), (5) and (6) were statistically significant for the protein yield. As for the milk yield, model (5) indicated a bias in the PIs. It seems that protein yield is not so sensitive to preferential treatment than the milk yield.

\section{Conclusions}

The way the herd effect is modelled for the current national breeding value estimation has clear- ly reduced the bias in the PIs. Still, it was found that a reflection of the bias, as has been found in the PIs of young sires, can be found in the PIs of their daughters. However, the magnitude of that bias was less than in earlier studies where the herd effect was modelled differently.

For the heifers of proven sires, the PIs were found to be reliable predictors of their first EBVs. Only for heifers with sires being unproved, the PIs overpredicted the EBVs on average by $78.8 \mathrm{~kg}$ in the milk yield and $2.2 \mathrm{~kg}$ in the protein yield. This bias is likely to be due to biased bull dam EBVs which will cause an overestimation of the young sires' breeding values. Hence, selecting outstanding heifers from the daughters of young sires to become bull dams of the next generation remains suspicious. The obtained EBVs for cows with superior dams conformed on average with their heifer PIs. That might imply that such animals enjoyed the same preferred environment as their dams, otherwise their first EBVs would have dropped like the first EBVs of the sons of bull dams do.

Furthermore, it was shown that the magnitude of the bias depends slightly on the size of the PI. The analysis indicated some bias in the PIs for heifers at the extremes, when the heifers had a proven sire or when they were daughters of a bull dam candidate. For heifers with a young sire the bias in the PIs was strongest when their PIs were between the mean and 2 standard deviations above the mean. The fact that for all polynomial regressions the coefficient of determination was very small indicates that the dependency of the bias on the size of the PI is practically negligible. 


\section{AGRICULTURAL AND FOOD SCIENCE IN FINLAND}

Lidauer, M. \& Mäntysaari, E. Detection of bias in animal model pedigree indices of heifers

\section{References}

Ferris, T.A. \& Wiggans, G.R. 1991. Accuracy of animal model parent evaluations in predicting daughter yield deviations for Al sampled bulls. Journal of Dairy Science 74, Supplement 1: 265. Abstract.

Harbers, A.G.F., Lohuis, M.M. \& Dekkers, J.C.M. 1994. Correction for preferential treatment of MOET families by including an environmental correlation in genetic evaluations. Proceedings of the $5^{\text {th }}$ World Congress on $\mathrm{Ge}$ netics Applied to Livestock Production, Guelph, Ontario. Vol. 17: 11-14.

Kuhn, M.T., Boettcher, P.J. \& Freeman, A.E. 1994. Potential biases in predicted transmitting abilities of females from preferential treatment. Journal of Dairy Science 77: 2428-2437.

Mäntysaari, E.A. \& Sillanpää, M.J. 1993. Bias in pedigree indices of dairy bulls: Should the management group effects be fixed and should we use smaller heritability? $44^{\text {th }}$ Annual Meeting of the European Association for Animal Production, Aarhus, Denmark. Vol 1: 236-237. Abstract.

- \& Strandén, I. 1991. Animal model evaluation for production and reproduction traits in Finnish dairy cattle. $42^{\text {nd }}$ Annual Meeting of the European Association for Animal Production, Aarhus, Denmark. Vol 1: 96-97. Abstract.

Mao, I.L., Dong, M.C. \& Meadows, C.E. 1991. Selection of bulls for progeny testing using pedigree indices and characteristics of potential bull-dams' herds. Journal of Dairy Science 74: 2747-2756.

Powell, R.L. \& Norman, H.D. 1988. Accuracy of cow indexes according to repeatability, evaluation, herd yield, and registry status. Journal of Dairy Science 71: 22322240.

Reverter, A., Golden, B.L., Bourdon, R.M. \& Brinks, J.S. 1994. Technical note: Detection of bias in genetic predictions. Journal of Animal Science 72: 34-37.

Strandén, I. \& Mäntysaari, E.A. 1992. Animal model evaluation in Finland: Experience with two algorithms. Journal of Dairy Science 75: 2017-2022.

Uimari, P. \& Mäntysaari, E.A. 1993. Repeatability and bias of estimated breeding values for dairy bulls and bull dams calculated from animal model evaluations. Animal Production 57: 175-182.

- \& Mäntysaari, E.A. 1995. Relationship between bull dam herd characteristics and estimated breeding value of bull. Agricultural Science in Finland 4: 463-472.

Werf, J.H.J. van der, Meuwissen, T.H.E. \& Jong, G. de. 1994. Effects of correction for heterogeneity of variance on bias and accuracy of breeding value estimation for Dutch dairy cattle. Journal of Dairy Science 77: 31743184

Wilhelm, A.E. \& Mao, I.L. 1989. Relationships between characteristics of herd of bull-dams and predicting transmitting ability of young bulls. Journal of Dairy Science 72: 2395-2401.

Zhang, W.C., Schaeffer, L.R., Dekkers, J.C.M. \& Deboer, H. 1994. Pedigree indexing of young Holstein bulls based on animal model evaluation. Proceedings of the $5^{\text {th }}$ World Congress on Genetics Applied to Livestock Production, Guelph, Ontario. Vol. 17: 15-18. 


\title{
AGRICULTURAL AND FOOD SCIENCE IN FINLAND
}

Vol. 5 (1996): 387-397.

\section{SELOSTUS}

\section{Eläinmalliin perustuvien hiehojen odotusarvojen luotettavuus jalostusarvon ennusteena}

\author{
Martin Lidauer ja Esa Mäntysaari \\ Maatalouden tutkimuskeskus
}

Tutkimuksen tavoitteena oli tutkia ovatko hiehojen odotusarvot (PI) harhaisia ja jos ovat, onko harha eri suuruinen eri hiehoryhmissä. Harhan arvioimiseksi laskettiin kahdet eläinmalliarvostelut kahden eri aineiston perusteella. Ensimmäinen aineisto käsitti kaikki 1978-94 poikineiden lehmien kolmen ensimmäisen tuotantovuoden 305 päivän maito- ja valkuaistuotostiedot. Toisesta tiedostosta poissuljettiin tuotantotiedot lehmiltä, jotka poikivat ensimmäisen kerran maaliskuun 1993 jälkeen, jolloin niiden jalostusarvoiksi muodostui isän ja emän arvosteluihin perustuva odotusarvo (PI). Arvostelujen jälkeen kertyi 51744 Ayrshire-lehmää, joilta oli sekä ensimmäisen tuotantovuoden tietoihin perustuva jalostusarvon ennuste (EBV), että karsitusta aineistosta laskettu PI. Tarkasteltavat eläimet jaettiin kolmeen eri kohderyhmään vanhempiensa perusteella: jälkeläisarvosteltujen keinosiemennyssonnien (valiosonnien) tyttäret, arvostelemattomien sonnien (nuorsonnien) tyttäret ja sonninemätasoisten emien tyttäret. Arvostelujen tuloksien testaamiseen käytettiin kolmea eri menetelmää: t-testiä, lineaarista regressiota EBV:stä PI:lle ja polyno- miaalista regressiota, jossa harhaa EBV-PI selitettiin PI:1lä.

Käytännössä merkittävästi harhaisia olivat vain nuorsonnien tyttärien odotusarvot. Keskimäärin niiden odotusarvot olivat vääristyneet ylöspäin 0,20 keskihajonnan yksikköä eli 78,8 kg maitotuotoksessa, ja 0,21 keskihajonnan yksikköä eli 2,2 kg valkuaistuotoksessa. Harhan oletettiin johtuvan nuorsonnien emien jalostusarvojen yliarvioinnista, joka aikaisemmissa tutkimuksissa on havaittu eläinmalliarvosteluille tyypilliseksi. Sonninemätasoisiksi luokiteltujen lehmien tyttärien odotusarvot tuntuivat ennustavan tyttärien tulevia jalostusarvosteluja melko luotettavasti. Tämän arveltiin saattavan johtua erityishuomiosta, jota karjanomistajat voivat antaa parhaiden lehmiensä tyttärille. Polynomiaalisen regression erittely osoitti, että keskimääräinen harhaisuuden aste muuttui hieman odotusarvon suuruuden mukaan, joskin ko. mallin antaman alhaisen selitysasteen perusteella PI:n suuruus ei käytännössä anna merkittävää lisätietoa odotusarvon luotettavuudesta. 